\title{
Soybean blotchy mosaic virus, a New Cytorhabdovirus Found in South Africa
}

\author{
R. L. Lamprecht, Department of Microbiology and Plant Pathology, Faculty of Natural and Agricultural Sciences, \\ University of Pretoria, Pretoria, 0002, South Africa; G. G. F. Kasdorf, M. Stiller, and S. M. Staples, Agricultural \\ Research Council-Plant Protection Research Institute, Queenswood, 0121, Pretoria, South Africa; L. H. Nel, De- \\ partment of Microbiology and Plant Pathology, Faculty of Natural and Agricultural Sciences, University of Pretoria; \\ and G. Pietersen, Agricultural Research Council-Plant Protection Research Institute, Queenswood
}

\begin{abstract}
Lamprecht, R. L., Kasdorf, G. G. F., Stiller, M., Staples, S. M., Nel, L. H., and Pietersen, G. 2010. Soybean blotchy mosaic virus, a new Cytorhabdovirus found in South Africa. Plant Dis. 94:1348-1354.

A previously unidentified plant Rhabdovirus sp. associated with a blotchy mosaic symptom of soybean (Glycine max), prevalent in the lower-lying, warmer soybean production areas of South Africa, was isolated and partially characterized. The virus was shown to be transmitted by mechanical inoculation and at least one species of leafhopper (Peragallia caboverdensis Lindberg (Cicadellidae, Agalliinae)). To determine the morphology and virion size, as well as intercellular accumulation, negative-stained preparations or embedded ultrathin sections of infected plant samples were observed under a transmission electron microscope. The distribution of the virions within the cytoplasm and its bullet-shaped morphology and size ( 338 to $371 \mathrm{~nm}$ by $93 \mathrm{~nm}$ ) suggested that it is a putative member of the genus Cytorhabdovirus. Degenerate primers designed to a conserved region of the polymerase gene of a number of Rhabdovirus spp. were used in reverse-transcriptase polymerase chain reaction with total RNA from symptomatic plants as template. Amplicons were sequenced and compared with related sequences available on GenBank. The analysis confirmed that the virus was related to Cytorhabdovirus spp., with the highest nucleotide similarity being $60.7 \%$ with Northern cereal mosaic virus. The particle morphology, typical virion accumulation in the cytoplasm of infected cells, nucleotide sequence similarity with that of other plant Rhabdovirus spp., and unique symptoms on soybean suggest that the virus is a previously unknown Cytorhabdovirus sp., for which we propose the name Soybean blotchy mosaic virus (SbBMV).
\end{abstract}

During a survey of the viruses of soybean (Glycine max Merr.) of South Africa conducted from 1993 to 1995, an unknown virus-like disease was commonly found in the Brits/Thabazimbi soybean production area of the Northwest Province and Groblersdal/Loskopdam area of Mpumalanga (23), among the main soybean production areas of South Africa. Typically affected soybean plants displayed distinct blotchy mosaic symptoms (Fig. 1) on the leaves. Preliminary morphological characterization of the virus had suggested that it was a Rhabdovirus sp. $(21,23)$. Soybean is an important crop in South Africa where, on average, 190,000 tons are produced annually, and investigation into diseases that may affect the yield of the crop is of considerable importance.

The aims of this study were to identify and partially characterize the putative Rhabdovirus sp. associated with the blotchy mosaic disease of soybean in South Africa.

Corresponding author: R. Lamprecht
E-mail: renatelamprecht@ sun.ac.za

Accepted for publication 21 July 2010

doi:10.1094/PDIS-09-09-0598

(C) 2010 The American Phytopathological Society

\section{MATERIALS AND METHODS}

Virus sources and sample collection. Plants with the characteristic blotchy mosaic symptoms associated with Rhabdovirus sp. infection and a range of similar mosaic-like symptoms were collected annually since 1993, during midsummer, from the major soybean production areas of Limpopo, Gauteng, Mpumalanga, and North Western Province. Plants were immediately placed in labeled plastic bags and kept at $4{ }^{\circ} \mathrm{C}$ until further tests were performed. Prior to the production of a virus-specific antiserum, leaf material was examined for viral particles as described by Hamilton et al. (9) by negative staining with $2 \%$ uranyl acetate, $\mathrm{pH} 3.8$, and examination with an ABT 002A electron microscope. Subsequently, plants were tested by immunoelectron microscopy (IEM) as described below. For molecular analysis, symptomatic soybean leaves from a single site in the Brits/Thabazimbi area were stored at $-70^{\circ} \mathrm{C}$ until RNA extraction or polymerase chain reaction (PCR) was conducted.

Virus culture establishment and transmission. A number of methods for virus transmission (20) were assessed in order to establish, maintain, and propagate the virus within the laboratory.
Grafting. Side cleft, bottle, and approach grafting $(3,7)$ using field-collected, infected soybean plants as the donor, were performed. Healthy soybean cvs. Forrest or B66S10 were used as recipient plants. Grafted plants were maintained for 6 to 8 weeks under insect-free conditions in a greenhouse under natural light conditions.

Insect transmission. Various leafhoppers, considered the most likely group of vectors due to their abundance, were collected from soybean fields in which the blotchy mosaic symptoms were prevalent. Live leafhoppers were sorted into morphologically identical groups (morphogroups) based on color, shape, and size, and each morphogroup separately exposed to healthy soybean cv. Forrest plants within insect-proof cages. Plants were monitored for symptoms for a 12-week period. Following the appearance of symptoms after exposure to one leafhopper morphogroup, this insect was maintained in the laboratory on soybean Forrest or B66S10 plants in insect cages under a single 400W HPS SON light with a 14- and 10-h (light and darkness, respectively) photoperiod at 22 to $28^{\circ} \mathrm{C}$. All subsequent insect transmissions were performed with leafhopper individuals from this colony by exposing healthy insects to symptomatic plants for 1 week, before transferring them to healthy soybean plants for 3 weeks and then removing the plants and treating them with an insecticide. Peragallia caboverdensis (18) was routinely identified in this colony (M. Stiller, unpublished data). Subsequently, voucher material has been deposited in Biosystematics division of the ARC-Plant Protection Research Institute, Pretoria (South Africa) under accession numbers CCDL21647 (4 specimens) CCDL21648 (3 specimens), and CCDL21649 (12 specimens).

Mechanical transmission. Mechanical transmission was done as published previously (22). Four individuals of each species or cultivar were inoculated with Soybean blotchy mosaic virus (SbBMV). These were Arachis hypogaea cv. Sellie (groundnut); Beta vulgaris; Chenopodium amaranticolor; C. murale; C. quinoa; Datura stramonium; soybean cvs. A5304, A5308, A5474, A7119, A7372, B66S10, Edgar, Forrest, Hutton, Highveld Top, Ibis, PNR577G, and PNR855; Gomphrena globosa; Lupinus albus cv. Kiev; Lycopersi- 
con esculentum cv. Rhodade; Nicotiana benthamiana; N. clevelandii; N. glutinosa; N. langsdorfii; N. occidentalis; N. rustica; N. tabacum cvs. Samsun, A4, TL33, and OD86; Phaseolus vulgaris cvs. Black Turtle Soup, Bonus, Bountiful, The Prince, Top Crop, and Redlands Greenleaf; Pisum sativum; Tetragonia expansa; Triticum aestivum; Vicia faba; Vigna unguiculata cv. Blackeye; and Zea mays. Inoculated plants were kept in insect-free greenhouses and were monitored for symptoms over a 6- to 8-week period and tested for virus by IEM.

Virus isolation and propagation. Isolation of the Rhabdovirus sp. was by serial limiting dilution mechanical inoculation transfers. Virus was propagated on soybean using leafhopper transmission or between $N$. benthamiana plants by mechanical transmission.

Virus purification and antiserum production. Rhabdovirus sp. infection, and a lack of other viruses, was confirmed by electron microscopy in individual fieldcollected soybean cv. Prima plants displaying blotchy mosaic symptoms before they were pooled and purified by the method of Adam et al. (1). Antiserum to the partially purified virus preparation was prepared by immunizing a New Zealand white rabbit with four weekly intramuscular injections. Immunoglobulins (Igs) were purified from antiserum with the use of carboxy methyl (CM) Affigel blue columns, according to the manufacturer's instructions (BioRad). The $\mathrm{F}\left(\mathrm{ab}^{\prime}\right)_{2}$ fragment of purified Igs were prepared by pepsin digestion (4). The optimal concentrations of seroreagents of $\mathrm{F}\left(\mathrm{ab}^{\prime}\right)_{2}$ enzyme-linked immunosorbent assay (ELISA; 2) were determined using a checkerboard titration design (31). The optimal sero-reagent combination was chosen as that which gave the highest differentiation between healthy and infected plant material extracts.

Transmission electron microscopy. To determine the morphology and virion size, leaf dips of infected plants were negatively stained and examined as described above. Tobacco mosaic virus (TMV) was used as an external standard to calibrate magnifications. Individual particle dimensions $(n=$ 55) were then measured on electron micrographs, relative to TMV. To observe the intercellular particle distribution, embedded ultrathin sections (30) of infected plant material were observed under a Philips EM301 transmission electron microscope.

IEM was conducted as described by Roberts (28) with virus trapped on colloidion-coated grids with a 1:100 dilution of the antiserum produced above.

RNA extraction and degenerate primer design. Viral RNA was extracted from infected plant material using the SV Total RNA Isolation System (Promega Corp., Madison, WI) according to the method described by the manufacturers. Primer design was described previously
(17). In short, ClustalW in BioEdit version 7.0.0 (8) was used to perform a multiple alignment of the $L$ gene of various $\mathrm{Nu}$ cleorhabdovirus spp.: Sonchus yellow net virus (SYNV, GenBank accession number L32609), Rice yellow stunt virus (RYSV, $\mathrm{AB} 00125)$, Maize mosaic virus (MMV, AY618418), and Taro vein chlorosis virus (TaVCV, AY674964); and Cytorhabdovirus spp.: Lettuce necrotic yellows virus (LNYV, NC007642), Northern cereal mosaic virus (NCMV, NC002251), and Strawberry crinkle virus (SCV, AY250986) available on GenBank (Table 1). Degenerate primers were designed to relatively conserved regions of the $L$ genes. These degenerate primers were expected to be broadly reactive to plant Rhabdovirus spp.

Reverse-transcriptase-PCR. For reverse-transcriptase (RT)-PCR, conserved areas of known plant Rhabdovirus $L$ genes were targeted and degenerate primers RhabF (5'-GGATMTGGGGBCATCC-3') and RhabR (5'-GTCCABCCYTTTTGYC$\left.3^{\prime}\right)$ were used from previous studies (17). The expected amplicon from this primer set was approximately $900 \mathrm{bp}$, depending on the Rhabdovirus sp. detected. RT-PCR was carried out on total RNA extracted from symptomatic soybean leaves. For cDNA synthesis, $8.5 \mu \mathrm{l}$ of RNA and $2 \mu \mathrm{l}$ of RhabF $(10 \mathrm{pmol})$ were incubated at $65^{\circ} \mathrm{C}$ for $10 \mathrm{~min}$ and cooled on ice for $2 \mathrm{~min}$. Then, 5x Expand Reverse Transcriptase Buffer, dithiothreitol at $100 \mathrm{mmol} / \mathrm{liter}, 10$ mM dNTPs, $40 \mathrm{U}$ of RNase Inhibitor, and Expand Reverse Transcriptase (Roche, Switzerland) were added and incubated at $43^{\circ} \mathrm{C}$ for $1 \mathrm{~h}$. LNYV RNA was kindly supplied by R. Dietzgen (University of Queensland, St. Lucia, Australia) and cDNA synthesis of LNYV was also performed as mentioned above and used as a cDNA and PCR control. PCR reactions of 50- $\mu \mathrm{l}$ reaction volumes were prepared. The reaction mixture consisted of $5 \mu \mathrm{l}$ of $10 \times$ reaction buffer (Bioline, UK), $50 \mathrm{mM}$ $\mathrm{MgCl}_{2}, 40 \mathrm{mM}$ dNTPs, 10 pmol of each primer, and $2.5 \mathrm{U}$ of Taq polymerase (Bioline). Finally, $5 \mu \mathrm{l}$ of the cDNA template was added, and the volume made up to 50 $\mu \mathrm{l}$ with UHQ water. The cycle conditions, on an ABI GeneAmp PCR System 2700 (PE Applied Biosystems, CT), were as follows: one cycle at $94^{\circ} \mathrm{C}$ for $2 \mathrm{~min}$; then, 35 cycles of $94^{\circ} \mathrm{C}$ for $30 \mathrm{~s}, 37^{\circ} \mathrm{C}$ for $30 \mathrm{~s}$, and $72^{\circ} \mathrm{C}$ for $90 \mathrm{~s}$; followed by one final cycle at $72^{\circ} \mathrm{C}$ for $7 \mathrm{~min}$. Amplicons were

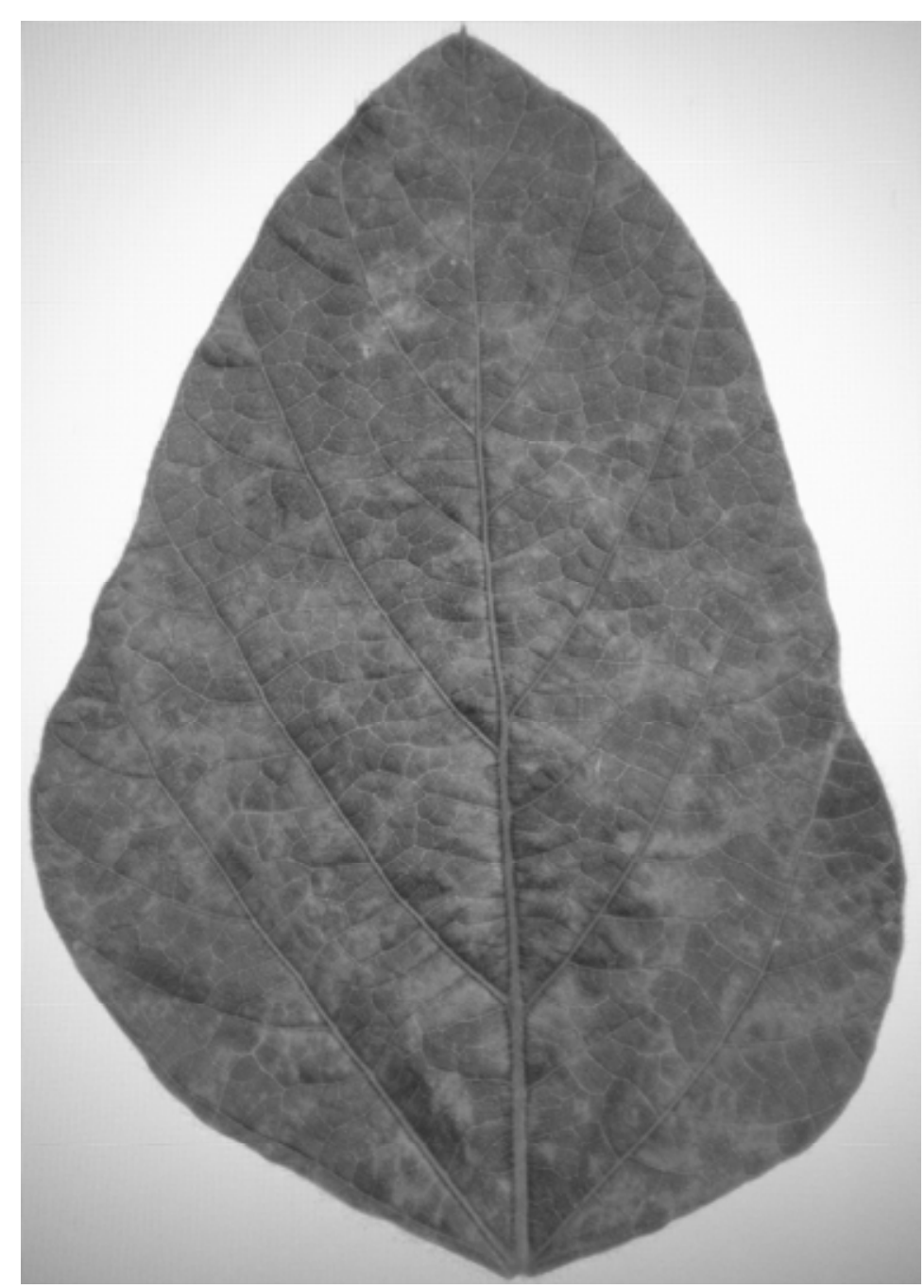

Fig. 1. Typical blotchy mosaic symptoms with which Soybean blotchy mosaic virus is associated. 
analyzed on a Tris-acetate-EDTA-buffered $1 \%$ agarose gel with a O'GeneRuler 200bp DNA Ladder Plus (Fermentas, Vilnius, Lithuania) and viewed under a UV transilluminator (Vilber Lourmat, France). An SCV partial cDNA clone of a pBluescript plasmid containing the $L$ gene sequence of SCV was kindly supplied by M. M. Goodin (University of Kentucky, Lexington) and was used as a PCR-positive control. PCR products of approximately 900 bp were purified from the gels using Wizard SV gel and PCR clean-up system (Promega Corp.).

Sequencing and sequence analysis. Sequencing reactions were performed using ABI Prism BigDye Primer Cycle Sequencing Kits (PE Applied Biosystems) according to the manufacturer's specifications. Sequencing was done with an autoDNA Sequencer; PE Applied Biosystems) mated fluorescent sequencer (ABI 377

at the University of Pretoria's commercial sequencing facility. Amplicons were directly sequenced in both directions using RhabF and RhabR primers. The sequences were analyzed by using the basic local alignment research tool (BLAST) program available on the National Centre for Biotechnology Information website (http:// ncbi.nlm.nih.gov/). The partial $L$ gene sequence obtained from soybean plants with the unidentified Rhabdovirus sp. was aligned and compared with the polymerase genes of available Cytorhabdovirus spp. NCMV (NC002251), SCV (AY250986), LNYV (NC007642), and Lettuce yellows mosaic virus (LYMoV, accession number EF687738), as well as to available $\mathrm{Nu}$ cleorhabdovirus spp. RYSV (AB001125), SYNV (L32603), MMV (AY618418), Maize fine streak virus (MFSV, AY618417), TaVCV (AY674964), and the unassigned Orchid fleck virus (OFV,

Table 1. Available sequences of plant Rhabdovirus spp. on GenBank

\begin{tabular}{lcc}
\hline Rhabdoviridae & Accession number & Reference \\
\hline Unassigned Rhabdoviridae & & \\
Orchid fleck virus (OFV) & NC009609 & 15 \\
Cynodon rhabdovirus (CRV) & EU650683 & 17 \\
Iranian maize mosaic virus (IMMV) & DQ186554 & 19 \\
Nucleorhabdovirus & & 5 \\
Sonchus yellow net virus (SYNV) & L32603 & 12 \\
Rice yellow stunt virus (RYSV) & AB001125 & 26 \\
Maize mosaic virus (MMV) & AY618418 & 25 \\
Maize fine streak virus (MFSV) & AY618417 & 27 \\
Taro vein chlorosis virus (TaVCV) & AY674964 & \\
Cytorhabdovirus & & 6 \\
Lettuce necrotic yellows virus (LNYV) & NC007642 & 10 \\
Lettuce yellow mottle virus (LYMoV) & EF687738 & 29 \\
Northern cereal mosaic virus (NCMV) & NC002251 \\
Strawberry crinkle virus (SCV) & AY250986 & 13,24 \\
\hline
\end{tabular}

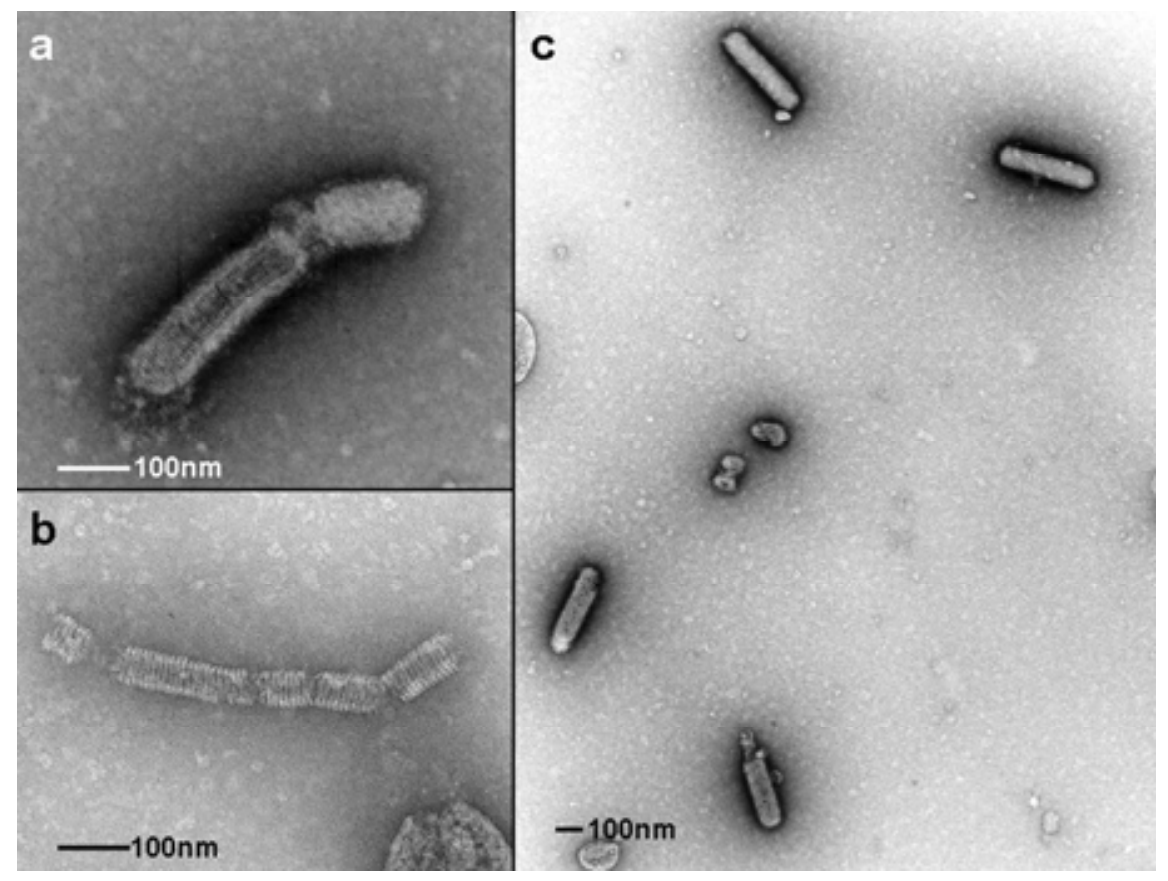

Fig. 2. Electron micrograph of $\mathbf{a}$ and $\mathbf{b}$, symptomatic soybean leaf material subjected to negative staining and showing a typical Rhabdovirus sp.-like particle of a, Soybean blotchy mosaic virus (SbBMV) and $\mathbf{b}$, nucleocapsid of SbBMV or $\mathbf{c}$, immunoelectron microscopy using antisera produced to SbBMV.
NC009609), Iranian maize mosaic virus (IMMV, DQ186554), and Cynodon rhabdovirus (CRV, EU650683) by doing a multiple alignment with ClustalX in BioEdit version 7.0.0 (8). From this alignment, SbBMV was compared with the same cognate region of other plant Rhabdovirus $\mathrm{spp}$. for analysis. The pairwise distance (pdistance) of cognate regions of the unidentified soybean Rhabdovirus sp. compared with known plant Rhabdovirus spp. were calculated and a neighbor-joining phylogenetic tree was constructed using the Mega Version 3.1 (16).

\section{RESULTS}

Virus sources and distribution of disease. In total, 1,303 samples displaying the blotchy mosaic-like symptoms were collected. The vast majority of these were collected in either the Brits/Thabzimbi area (North West Province) or GroblersdalLoskopdam area (Mpumalanga) (626 and 436 samples, respectively) because the disease appeared more prevalent in these areas. Symptomatic plants were less prevalent in the Mpumalanga Lowveld and Limpopo Province, where 74 and 109 samples, respectively, were collected. No examples of the typical blotchy mosaic symptoms were obtained from the $\mathrm{Mpu}$ mulanga or Gauteng Highveld regions, where 58 samples with other types of mosaic symptoms were collected. Samples were tested for virus by either negative staining followed by electron microscopy (EM) analysis (954 samples) or by IEM (349 samples). Rhabdovirus sp.-like particles at extremely low numbers were observed in 346 samples (36\%) among those subjected to negatively stained leaf dips (Fig. 2a and b), while 227 samples (65\%) had Rhabdovirus sp.-like particles at relatively low numbers in IEM tests. Flexuous, rod-shaped particles were often observed in negatively stained preparations, especially with samples where the symptoms were described as an "atypical type of blotchy mosaic". ELISA was conducted on 45 such plants to detect Cowpea aphidborne mosaic virus, Peanut mottle virus, and Soybean mosaic virus, all previously found in the same districts where the collection of blotchy mosaic symptomatic plants took place. All of these were infected with Soybean mosaic virus (results not shown). The Rhabdovirus-containing samples were restricted to the warmer, low-lying soybean production areas in the northern parts of South Africa, and were more prevalent in Brits/Thabazimbi, Northwest Province and Groblersdal/ Loskopdam, Mpumalanga. None of the samples collected from the Highveld regions of Gauteng or Mpumalanga contained Rhabdovirus sp.-like particles.

Virus establishment and transmission. Grafting of symptomatic field-collected plants from the Loskopdam and Brits/ Thabazimbi areas onto healthy soybean 
indicator plants was attempted with 66 samples (51 and 15 plants collected either early or late in the season, respectively). Of these, 20 samples were grafted immediately in the field while the remaining 46 samples were made with cuttings in the laboratory. Only eight successful graft unions were obtained, all from plants collected relatively early in the growth season and grafted in the laboratory with bottle grafting. In only three instances was transmission successful, with the recipient soybean plants developing blotchy mosaic symptoms after 3 to 4 weeks and containing virus particles when tested by IEM.

The various leafhopper individuals collected from soybean fields were sorted into two prevalent morphogroups while the remainder made up a further five groups. The two prevalent leafhopper groups were Peragallia caboverdensis (Cicadellidae; Agallinae; Agalliini) and an unidentified species of Empoasca (Cicadellidae; Typhlocybinae; Empoascini). Identification of the latter species was not possible due to the limited taxonomic work of this group in the Afrotropical Region. Transmission of the Rhabdovirus sp. was achieved by allowing individuals of $P$. caboverdensis to feed directly on unrooted cuttings for 7 days and then transferring them to healthy plants. The soybean indicator plants showed typical blotchy mosaic symptoms after 2 months, and virus particles could be detected in the plants by IEM. The $P$. caboverdensis colony was reared and maintained on soybean plants for 3 years without the appearance of any blotchy mottle-like symptoms on these plants, suggesting that the colony was nonviruliferous. Propagation of the virus by transmission to soybean plants using individuals from the $P$. caboverdensis colony was successful for two serial passages on three occasions with 20 plants per transmission, after which the virus could no longer be transmitted. Transmission rates varied between 10 and $30 \%$.

Mechanical transmission. Mechanical transmission of the Rhabdovirus sp. was achieved following a large number of initially unsuccessful attempts. Successful mechanical inoculation was achieved with young symptomatic leaf material, collected very early in the growth season and macerated in cold $0.01 \mathrm{M}$ phosphate buffer, $\mathrm{pH}$ 7.1, and immediately inoculated onto soybean cv. Forrest. Virus was transmitted to
Forrest from 5 of 13 field-collected samples. Further serial transmission to more Forrest plants was extremely inefficient, with less than $10 \%$ of plants becoming infected. Further serial mechanical transmission was done for four passages, after which virus was lost from all but one line. This source (accession number 95/0131) was used for subsequent studies on alternate host plants, virus purification, particle morphology, and distribution in the cell. The virus was considered isolated because it effectively passed through four seriallimiting dilution infections, in which less than $10 \%$ of plants became infected.

Among the host plants tested, mechanical transmission of the virus from soybean could only be demonstrated to soybean cvs. Forrest, Edgar, and Ibis and to N. benthamiana. Mechanical transmission from soybean to soybean was inefficient, with transmission occurring at frequencies less than $30 \%$. Mechanical transmission from soybean to $N$. benthamiana and between individual $N$. benthamiana plants resulted in symptomless infected plants but at transmission rates of 30 to $40 \%$.

Virus purification and antiserum production. During virus purification, a con-

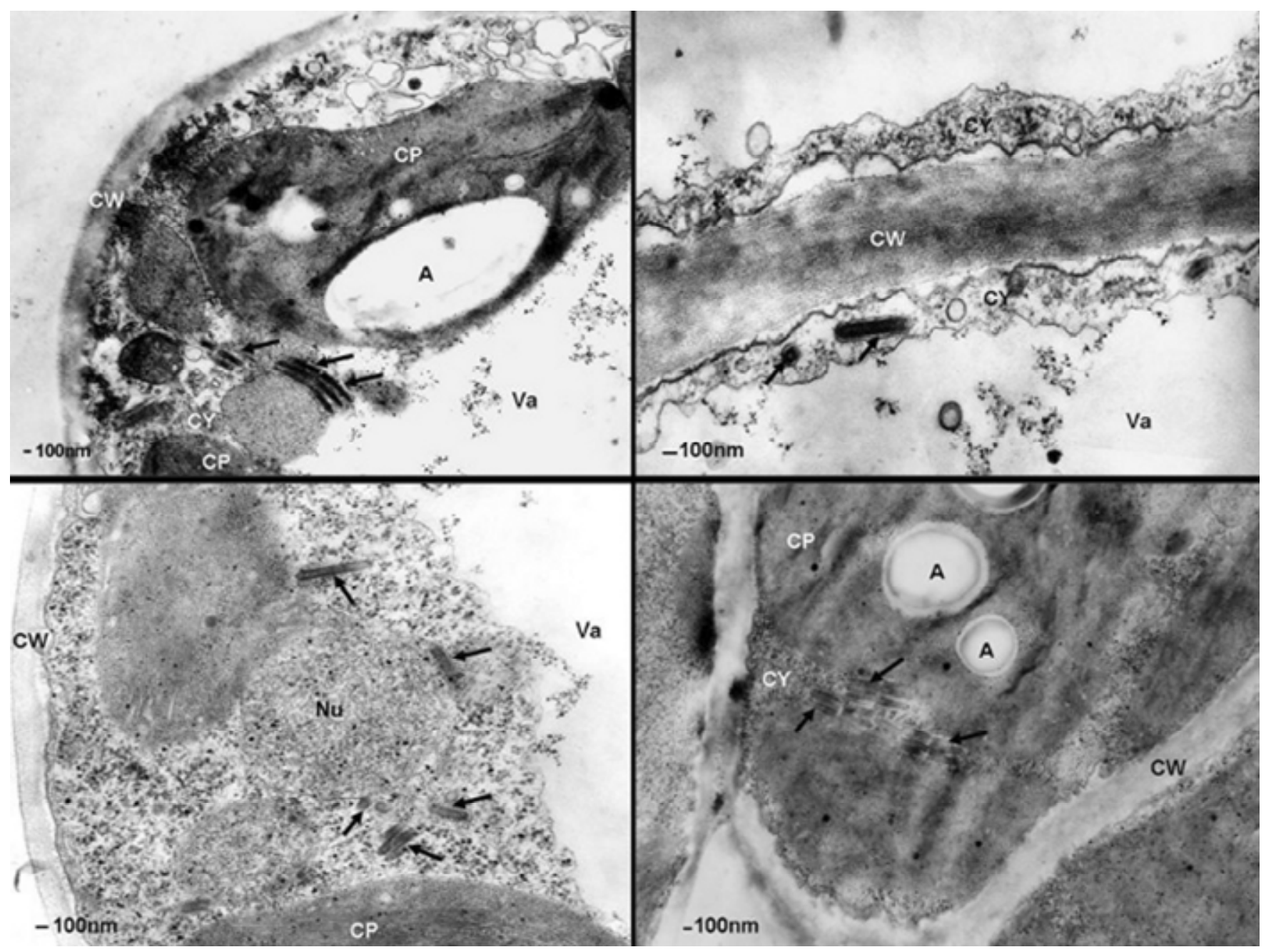

Fig. 3. Electron micrograph of ultrathin sections of embedded Soybean blotchy mosaic virus-infected soybean (accession no. 95/0131) showing typical Rhabdovirus sp.-like particles (arrows) occurring in the cytoplasm $(\mathrm{CY})$ of cells. $\mathrm{CP}=$ chloroplast, $\mathrm{CW}=$ cell wall, $\mathrm{A}=$ amyloplast, $\mathrm{Nu}=$ nucleoplasm, $\mathrm{Va}=$ vacuole . 
siderable loss of particles occurred at each step as determined by EM; therefore, only two rounds of differential centrifugation with a $20 \%$ (wt/vol) sucrose pad were conducted but the resultant partially purified virus was not placed on a final sucrose gradient. Six bleeds were obtained from a rabbit immunized with four injections of a partially purified virus preparation but the antiserum was found not to be suitable for use in ELISA due to a high nonspecific response to healthy plant components even following cross absorption of antiserum with healthy plant material (results not shown). However, the antiserum could be used in IEM, with virus particle enrichment being increased fivefold relative to preimmune serum (Fig. 2c).

Virus morphology. Symptomatic soybean cv. Forrest plants were used to determine virus particle morphology and the intercellular distribution of the particles using transmission electron microscopy on ultrathin sections of embedded material or negatively stained leaf dips. Bullet-shaped virions were found in very low numbers in the cytoplasmic areas (Fig. 3). The average $(n=55)$ length of the virions as determined by negative staining of leaf preparations was $360 \mathrm{~nm}$, with a minimum length

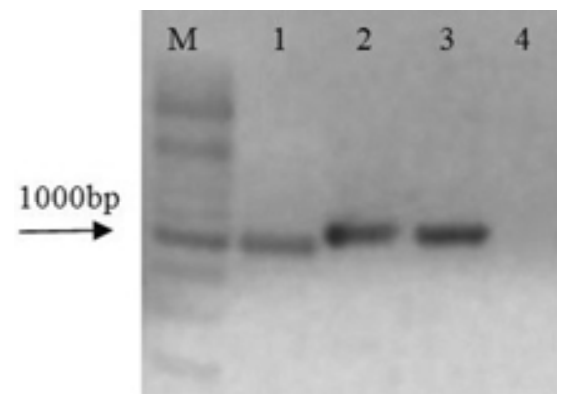

Fig. 4. Reverse-transcriptase polymerase chain reaction amplification of $L$ gene fragment of Soybean blotchy mosaic virus (SbBMV) using degenerate primers. Samples were analyzed on a $1 \%$ agarose gel and stained with EtBr. Lane M, O'GeneRuler 200-bp DNA Ladder Plus; lane 1, Strawberry crinkle virus; lane 2, Lettuce necrotic yellows virus; lane 3, SbBMV; and lane 4, negative, water control. of $180 \mathrm{~nm}$ and a maximum of $420 \mathrm{~nm}$, with most particles found in a range of 338 to $371 \mathrm{~nm}$ without a clear modal length. The width varied between 79 and $93 \mathrm{~nm}$ (Fig. 2). This size distribution falls within the size range of the Rhabdoviridae (14).

Amplification and sequencing. The amplicon obtained with the primer set was an approximately 900-bp segment from SCV, LNYV, and SbBMV (Fig. 4). The PCR product was purified from the gel and directly sequenced in both directions using RhabF and RhabR. RhabF proved to be a poor primer for sequencing and only the sequence generated by RhabR could be used, and a 522-bp nucleotide sequence was obtained. BLAST analysis confirmed that the PCR amplicon was of viral RNA (polymerase gene) origin and that it was most closely related to known Cytorhabdovirus polymerase genes. The sequence was submitted to GenBank with the accession number EU877231.

Sequencing analysis. Pairwise distances of SbBMV to other polymerase genes of different plant Rhabdovirus spp. were calculated using a cognate region of 410 bp with MEGA 3.1 (16). The SbBMV had the highest similarity to NCMV, with $60.7 \%$, and then LNYV and SCV (59.3 and $58.5 \%$, respectively), followed by the other plant Rhabdovirus spp. (Table 2).

A neighbor-joining phylogenetic tree (Fig. 5) was constructed with the same cognate region using Mega 3.1 (16). The tree separated the selected plant Rhabdovirus spp. into two distinct clades, correlating with the Cyto- and Nucleorhabdovirus genera. Within this analysis, the SbBMV was found to be most closely related to the Cytorhabdovirus spp., especially NCMV.

\section{DISCUSSION}

We have identified a new Cytorhabdovirus sp. associated at levels of 37 or $65 \%$ (depending on whether negative staining of leaf dips or IEM was used) with a blotchy mosaic disease of soybean $(G$. $\max$ ) in South Africa and propose the name Soybean blotchy mosaic virus (SbBMV), in view of its apt description of the disease with which it is associated. The relatively low level of association is considered primarily due to the relatively low number of virus particles found in leaves, the relative insensitivity of both techniques as used, and the fact that a number of samples were collected which were not considered typical blotchy mottle symptoms. A number of the samples, particularly among those lacking Rhabdovirus sp.-like particles, contained flexuous rod-shaped particles which, in the case of those tested by ELISA, were found to be particles of Soybean mosaic virus but could also include Cowpea aphid-borne mosaic virus or Peanut mottle virus, previously found on soybean in these areas (23), causing some of the atypical blotchy mosaic-type symptoms (22). Future studies, using a specific primer pair in PCR, need to be conducted to ascertain the exact nature of the disease associated with this virus. The disease is found annually during the growing season throughout the warmer low-lying soybeanproducing areas of South Africa, with incidences that vary from 0 to $32 \%$ in the individual fields. The sizes of the SbBMV particles fall within the range of those of other members of the family Rhabdoviridae. The sizes ranged from 180 to $420 \mathrm{~nm}$, with most between 338 and $371 \mathrm{~nm}$, and a width of 79 to $93 \mathrm{~nm}$ (negatively stained preparations of infected plants). In ultrathin sections of leaves, the virion particles were found in low numbers in the cytoplasm of infected soybean cells.

Identification and rapid detection of SbBMV has long been hampered by difficulties in establishing the virus in the greenhouse due to difficulties in transmitting the virus. However, during the current study, the development of an IEM technique with a relatively crude antiserum to virus partially purified from fieldcollected plant material, followed by the development of a generic Rhabdovirus sp. polymerase RT-PCR, was found to be a valuable tool for the maintenance and identification of this virus. An alternate propagation host to soybean (viz., $N$. benthamiana) was identified using IEM

Table 2. Similarity matrix of partial nucleotide sequences of the $L$ gene of plant Rhabdovirus spp. ${ }^{\text {a }}$

\begin{tabular}{|c|c|c|c|c|c|c|c|c|c|c|c|}
\hline Viruses & LNYV & MMV & NCMV & RYSV & SCV & SYNV & OFV & TaVCV & MFSV & LYMoV & SbBMV \\
\hline LNYV & & $\ldots$ & $\ldots$ & $\ldots$ & $\ldots$ & $\ldots$ & $\ldots$ & $\ldots$ & $\ldots$ & $\ldots$ & $\ldots$ \\
\hline MMV & 52.2 & $\ldots$ & $\ldots$ & $\ldots$ & $\ldots$ & $\ldots$ & $\ldots$ & $\ldots$ & $\ldots$ & $\ldots$ & $\ldots$ \\
\hline NCMV & 59 & 50 & $\ldots$ & $\ldots$ & $\ldots$ & $\ldots$ & $\ldots$ & $\ldots$ & $\ldots$ & $\ldots$ & $\ldots$ \\
\hline RYSV & 50.7 & 56.3 & 53.7 & $\ldots$ & $\ldots$ & $\ldots$ & $\ldots$ & $\ldots$ & $\ldots$ & $\ldots$ & $\ldots$ \\
\hline SCV & 68.8 & 51 & 56.3 & 51 & $\ldots$ & $\ldots$ & $\ldots$ & $\ldots$ & $\ldots$ & $\ldots$ & $\ldots$ \\
\hline SYNV & 46.6 & 55.1 & 49.8 & 53.7 & 47.3 & $\ldots$ & $\ldots$ & $\ldots$ & $\ldots$ & $\ldots$ & $\ldots$ \\
\hline OFV & 48.8 & 55.6 & 54.1 & 54.6 & 49.3 & 59 & $\ldots$ & $\ldots$ & $\ldots$ & $\ldots$ & $\ldots$ \\
\hline TaVCV & 53.2 & 72 & 53.9 & 57.1 & 56.1 & 53.7 & 53.9 & $\ldots$ & $\ldots$ & $\ldots$ & $\ldots$ \\
\hline MFSV & 51.7 & 58.3 & 53.7 & 52.7 & 54.1 & 59.3 & 58.5 & 58.5 & $\ldots$ & $\ldots$ & $\ldots$ \\
\hline LYMoV & 73.9 & 50.5 & 58 & 53.9 & 70 & 47.6 & 50.5 & 51.5 & 52.2 & $\ldots$ & $\ldots$ \\
\hline SbBMV & 59.3 & 49.8 & 60.7 & 53.4 & 58.5 & 49.5 & 51.5 & 51.7 & 51.7 & 56.8 & $\ldots$ \\
\hline CRV & 50.7 & 69.7 & 51.5 & 56.3 & 53.9 & 54.4 & 51.7 & 71 & 57.3 & 51.2 & 48.8 \\
\hline
\end{tabular}

a Relative sequence similarity to Soybean blotchy mosaic virus (SbBMV) is shown in bold. The similarity matrix was calculated using Mega 3.1 (16). LNYV $=$ Lettuce necrotic yellows virus, MMV = Maize mosaic virus, NCMV $=$ Northern cereal mosaic virus, RYSV $=$ Rice yellow stunt virus, SCV $=$ Strawberry crinkle virus, SYNV = Sonchus yellow net virus, OFV = Orchid fleck virus, TaVCV = Taro vein chlorosis virus, MFSV = Maize fine streak virus, $\mathrm{LYMoV}=$ Lettuce yellow mottle virus, and CRV = Cynodon rhabdorirus. 
but was difficult to work with because it was asymptomatic, and individual inoculated plants required IEM tests to be conducted to ascertain their status. The virus was found to be mechanically transmissible between soybean plants, between soybean and $N$. benthamiana, and among $N$. benthamiana plants at low transmission rates.

Because of the large numbers of leafhoppers observed in a local soybean field, and the fact that a number of other Rhabdovirus spp. are known to be transmitted by these insects (11), we determined whether these insects could serve as vectors for SbBMV. One of two prevalent morphogroups among field-collected individuals, later identified as $P$. caboverdensis, could transmit the disease to healthy soybean plants. A nonviruliferous colony of this species was used to confirm the transmission under laboratory conditions. Further leafhopper species present locally may also serve as vectors and further studies are required to determine this, along with transmission characteristics of $P$. caboverdensis. This species has been collected on a very wide range of plants in Southern Africa, such as species of Graminea and many dicotyledonous familife cycle needs examination to determine disease and vector control protocols.

Sequence information for SbBMV generated during this study indicated that it is related to Cytorhabdovirus spp., particularly to NCMV. Based on the morphological and nucleotide sequence data, we concluded that the virus belongs to the genus Cytorhabdovirus, family Rhabdoviridae and, in view of its low sequence similarity with known Rhabdovirus spp., we propose that it be considered a new species and be lies (M. Stiller, personal observation). Its

named Soybean blotchy mosaic virus (SbBMV).

Among the known plant Rhabdovirus spp., only SCV (13,24), CRV (17), and now SbBMV have been reported from South Africa. In view of the extensive indigenous flora in South Africa, it is likely that many more plant Rhabdovirus spp. may occur here. The universal Rhabdovirus sp. protocol used in this study could also be used as a tool to detect known as well as new plant Rhabdovirus spp. in field studies, broadening our understanding of the epidemiology of these viruses. Thus far, the degenerate primers RhabF and RhabR were employed to amplify four different plant Rhabdovirus spp., including the two new putative plant Rhabdovirus spp., SbBMV and CRV (17).

Further studies are needed to develop primers and an SbBMV-specific RT-PCR to (i) confirm the association of this virus with the disease; (ii) prove that the virus is the etiological agent of the disease; (iii) study the possibility that other leafhopper species may vector the virus; (iv) determine the natural alternate host of the virus during winter when soybean fields lie fallow; and (v) better characterize the virus with regards to its transmission, genome, translation, and replication strategies. Methods to control the disease can only be efficiently applied once a number of these aspects are known.

\section{ACKNOWLEDGMENTS}

We thank R. Dietzgen (University of Queensland, Australia) and M. M. Goodin (University of Kentucky, Lexington) for supplying us with the LNYV RNA and SCV clone, respectively; A. Hall and C. van der Merwe (Department of Microscopy and Microanalysis, University of Pretoria, Pretoria, South Africa) for their aid and expertise with the EM sections; and H. J van Tonder (Agricultural Research Council-Plant Protection Research Insti-

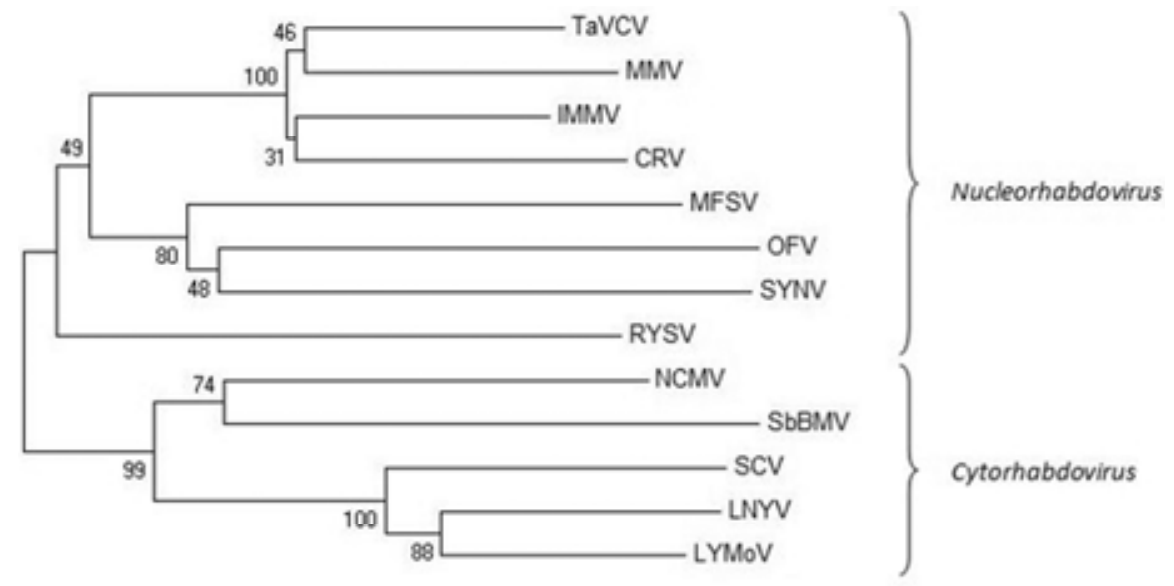

0.1

Fig. 5. Phylogenetic tree of partial nucleotide sequences of Soybean blotchy mosaic virus (SbBMV) and other plant Rhabdovirus spp. Tree was constructed using MEGA 3.1 using the neighbor-joining method (16). TaVCV = Taro vein chlorosis virus, $\mathrm{MMV}=$ Maize mosaic virus, IMMV = Iranian maize mosaic virus, CRV = Cynodon rhabdovirus, MFSV = Maize fine streak virus, OFV = Orchid fleck virus, SYNV = Sonchus yellow net virus, RYSV = Rice yellow stunt virus, NCMV = Northern cereal mosaic virus, $\mathrm{SCV}=$ Strawberry crinkle virus, $\mathrm{LNYV}=$ Lettuce necrotic yellows virus, and $\mathrm{LYMoV}=$ Lettuce yellow mottle virus. tute, Queenswood, Pretoria, South Africa) for assistance in cytological examinations.

\section{LITERATURE CITED}

1. Adam, G., Chagas, C. M., and Lesemann, D.E. 1987. Comparison of three rhabdovirus isolates by two different serological techniques. Phytopathology 120:31.

2. Barbara, D. J., and Clark, M.F. 1982. A simple indirect ELISA using $\mathrm{F}\left(\mathrm{ab}^{\prime}\right) 2$ fragments of immunoglobulin. J. Gen. Virol. 58:315-22.

3. Bos, L. 1967. Graft transmission of plant viruses. Methods Virol. 1:403-410.

4. Campbell, D. H., Garvey, Z. S., Cremer, N. E., and Sussdorf, O. H 1970. Pages 224-232 in: Methods in Immunology, 2nd ed. W. A. Benjamin, Reading, MA.

5. Choi, T.-J, Kuwata S., Koonin E. V., Heaton L., and Jackson A. O. 1992. Structure of the L (polymerase) protein gene of sonchus yellow net virus. Virology 189:31-39.

6. Dietzgen, R. G., Callaghan B., Wetzel T., and Dale J. L. 2006. Completion of the genome sequence of Lettuce necrotic yellows virus, type species of the genus Cytorhabdovirus. Virus Res. 118:16-22.

7. Gibbs, A., and Harrison, B. 1976. Experimental transmission. Chapter 4 in: Plant Virology The Principles. Edward Arnold Publishers Ltd., London.

8. Hall, T. A. 1999. BioEdit: a user-friendly biological sequence alignment editor and analysis program for Windows 95/98/NT. Nucleic Acids Symp. Ser. 41:95-98.

9. Hamilton, R. I., Edwardson, J. R., Francki, R. I. B., Hsu, H. T., Hull, R., Koenig, R., and Milne, R. G. 1981. Guidelines for the identification and characterization of plant viruses. J. Gen. Virol. 54:223-241.

10. Heim, F., Lot, H., Delecolle, B., Bassler, A., Krezal, G., and Wetzel, T. 2008. Complete nucleotide sequence of a putative new cytorhabdovirus infecting lettuce. Arch. Virol. 153:8192.

11. Hogenhout, S. A., Redinbaugh M. G., and Ammar, E. D. 2003. Plant and animal rhabdovirus host range: a bug's view. Trends Microbiol. 11:264-271.

12. Huang, Y., Zhao, H., Luo, Z., Chen, X., and Fang, R. X. 2003. Novel structure of the genome of Rice yellow stunt virus: identification of the gene 6-encoded virion protein. J. Gen. Virol. 84:2259-2264.

13. Hunter, B. G., Richardson, J., Dietzgen, R. G., Karu, A., Sylvester, E. S., Jackson, A. O., and Morris, T. J. 1990. Purification and characterization of strawberry crinkle virus. Phytopathology 80:282-287.

14. Jackson, A. O., Dietzgen, R. G., Goodin, M. M., Bragg, J. N., and Deng, M. 2005. Biology of plant rhabdoviruses. Annu. Rev. Phytopathol. 43:623-660.

15. Kondo, H., Maeda, T., Shikaro, Y., and Tamada, T. 2006. Orchid fleck virus is a rhabdovirus with an unusual bipartite genome. $\mathrm{J}$. Gen. Virol. 87:2413-2421.

16. Kumar, S., Tamura K., and Nei, M. 2004 MEGA3: Integrated software for molecular evolutionary genetics analysis and sequence alignment. Brief. Bioinf. 5:150-153.

17. Lamprecht, R. L., Pietersen, G., Kasdorf, G. G. F., and Nel, L. H. 2008. Characterisation of a proposed nucleorhabdovirus new to South Africa. Eur. J. Plant Pathol. 123:105-110.

18. Lindberg, H. 1958. Hemiptera Insularum Caboverdensium. Systematik, Ökolgie und Verbreitung der Heteropteren und Cicadinen der Kapverdischen Inseln. Commentat. Biol. Soc. Sci. Fenn. 19:1-246.

19. Massah, A., Izadpanah, K., Afsharifar, A. R., and Winter, S. 2008. Analysis of nucleotide sequence of Iranian maize mosaic virus confirms its identity as a distinct nucleorhabdovirus. Arch. Virol. 153:1041-1047. 
20. Noordam, D. 1973. Identification of Plant Viruses: Methods and Experiments. Centre for Agricultural Publishing and Documentation, Wageningen, The Netherlands.

21. Pietersen, G. 1993. Importance of a rhabdovirus-associated disease of soybeans in South Africa. In: $6^{\text {th }}$ Int. Congress Plant Pathol. Quebec, Canada.

22. Pietersen, G., and Garnett, H. M. 1990. A survey for the viruses of soybeans (Glycine max) in. the Transvaal, South Africa. Phytophylactica 22:35-40.

23. Pietersen, G., Staples, S. M., Kasdorf, G. G. F., and Jooste, A. E. C 1998. Relative abundance of soybean viruses in South Africa. Afr. Plant Prot. 4:65-70.

24. Posthuma, K. I., Adams, A. N., Hong, Y., and Kirby, M. J. 2002. Detection of Strawberry crinkle virus in plants and aphids by RT-PCR using conserved $\mathrm{L}$ gene sequences. Plant Pathol. 51:266-274.

25. Redinbaugh, M. G., Seifers, D. L., Meulia, T., Abt, J. J., Anderson, R. J., Styer, W. E., Ackerman, J., Salomon, R., Houghton, W., Creamer, R., Gordon, D. T, and Hogenhout, S. A. 2002. Maize fine streak virus, a new leafhoppertransmitted rhabdovirus. Virology 92:11671173.

26. Reed, S. E., Tsai, C. W., Willie, K. J., Redinbaugh, M. G., and Hogenhout S. A. 2005. Shotgun sequencing of the negative-sense RNA genome of the rhabdovirus Maize mosaic virus. J. Virol. Methods 129:91-96.

27. Revill, P., Trihn, X., Dale, J., and Harding, R. 2005. Taro vein chlorosis virus: characterization and variability of a new nucleorhabdovi- rus. J. Gen. Virol. 86:491-499.

28. Roberts, I. M. 1986. Immuno-electron microscopy of extracts of virus-infected plants. Pages 293-357 in: Electron Microscopy of Proteins. J. R. Harris and R. W. Horne, eds. Academic Press, New York.

29. Tanno, F., Nakatsu, A., Toriyama, S., and Kojima, M. 2000. Complete nucleotide sequence of Northern cereal mosaic virus and its genome organization. Arch. Virol. 145:1373-1384.

30. Van der Merwe, C. F., and Coetzee, J. 1992 Quetol 651 for general use: a revised formulation. Proc. Electron Microsc. Soc. South Afr. 22:31-32.

31. Voller, A., Bidwell, D. E., and Bartlett, A 1979. The Enzyme-Linked Immunosorben Assay (ELISA). Dynatech Laboratories, Inc., Alexandria, VA. 